\title{
Repeated maternal glucocorticoid administration and the developing liver in fetal sheep
}

\author{
D M Sloboda, J P Newnham and J R G Challis ${ }^{1}$
}

School of Women's and Infants' Health, University of Western Australia, Perth, Australia

${ }^{1} \mathrm{CIHR}$ Group in Fetal and Neonatal Health and Development, Departments of Physiology and Obstetrics and Gynecology, University of Toronto, Toronto, Ontario, Canada

(Requests for offprints should be addressed to D M Sloboda, School of Women's and Infants' Health, University of Western Australia, King Edward Memorial Hospital, Subiaco, Western Australia 6008, Australia; Email: dsloboda@obsgyn.uwa.edu.au)

\begin{abstract}
Prenatal glucocorticoid exposure has been associated with a reduction in birth weight and postnatal alterations in glucose homeostasis and hypothalamic-pituitary-adrenal (HPA) axis function. The mechanisms underlying these responses are unknown, although changes in fetal hepatic development may play an important role. The fetal liver produces key regulators of fuel metabolism and of the developing HPA axis that are altered by glucocorticoids. The local availability of glucocorticoids is regulated, in part, by corticosteroid-binding protein $(\mathrm{CBG})$, glucocorticoid receptors (GR) and by the enzyme $11 \beta$ hydroxysteroid dehydrogenase (11ßHSD), but the effects of maternal glucocorticoid administration on the expression of these genes in the fetal liver are unknown. $11 \beta \mathrm{HSD} 1$ is the predominant form of this enzyme present in the liver and is responsible for the conversion of cortisone to cortisol. To determine if prenatal glucocorticoid exposure alters fetal hepatic regulation of CBG, $11 \beta$ HSD1 and GRs, we treated pregnant ewes with betamethasone $(0.5 \mathrm{mg} / \mathrm{kg})$ intramuscularly at 104,111 and 118 days of gestation (term 150 days). Animals were killed at 125 or 146 days of gestation. Maternal betamethasone administration did not alter mean cord plasma
\end{abstract}

glucose but significantly decreased cord plasma insulin levels $(P<0 \cdot 05)$ at 125 days of gestation. At 146 days of gestation, cord plasma glucose levels were significantly increased without alterations in insulin levels following maternal betamethasone treatment $(P<0 \cdot 05)$. Maternal betamethasone administration resulted in a significant increase in fetal hepatic 11ßHSD1 mRNA and protein levels at 125 days of gestation $(P<0 \cdot 05)$. CBG mRNA levels were significantly elevated over control at 125 days although levels of CBG protein were not significantly different. GR protein levels were not statistically different at either 125 or 146 days of gestation following glucocorticoid administration. These data suggest that prenatal betamethasone exposure in the ovine fetus results in alterations in cord glucose and insulin levels as well as alterations in hepatic $11 \beta \mathrm{HSD} 1 \mathrm{mRNA}$ and protein expression. These changes in $11 \beta \mathrm{HSD} 1$ increase the potential to generate local cortisol from circulating cortisone. We speculate that this could affect expression of glucocorticoid-dependent hepatic enzymes involved with the regulation of glucose production and HPA responsiveness.

Journal of Endocrinology (2002) 175, 535-543

\section{Introduction}

Numerous epidemiological studies have suggested that intrauterine factors are important determinants of the risk of developing a variety of adult diseases (Osmond et al. 1993, Barker 1994, 1998, McCance et al. 1994). Low birth weight has been associated with impaired glucose tolerance and insulin resistance in adulthood (Hales et al. 1991, Phipps et al. 1993, Lithell et al. 1996, Ravelli et al. 1998). The fetal programming hypothesis has been proposed to explain these associations. Programming reflects the possibility of an intrauterine factor mediating cellular growth and development at a vulnerable time in gestation, subsequently resulting in permanent alterations in tissue and organ function that are apparent later in life (Dennison et al. 1997, Barker 1998, Dodic et al. 1999, Hill 1999, Seckl \& Chapman 2000).

Alterations in hypothalamic-pituitary-adrenal (HPA) activity have been associated in adulthood with the development of insulin resistance and glucose intolerance, as well as hypertension (Phillips et al. 1998, Levitt et al. 2000). However, there are no data from human studies addressing prenatal glucocorticoid exposure with metabolic function; low birth weight has been studied as a potential surrogate for fetal glucocorticoid exposure and other intrauterine alterations. Epidemiological studies have shown that low birth weight is related to elevated levels of fasting plasma cortisol levels, elevated systolic blood 
pressure, plasma glucose and triglyceride levels and insulin resistance in adult men (Phillips et al. 1998). In experimental models, prenatal exposure to synthetic glucocorticoids results in decreased birth weight (Jobe et al. 1998, Sloboda et al. 2000) as well as elevations in fetal and postnatal HPA activity in sheep (Sloboda et al. 2000, 2001) and in primates (Uno et al. 1994). The role of the HPA axis in programming future metabolic function is also pertinent to the safety of clinical prenatal glucocorticoid treatment, since glucocorticoids are administered to women at risk of preterm birth to enhance lung function in current clinical practice (Liggins \& Howie 1972).

Although the mechanisms linking intrauterine growth restriction, HPA activity and metabolic function are poorly understood, studies suggest that prenatal glucocorticoids may target specific organs such as the liver and the pancreas (Lindsay et al. 1996, Nyirenda et al. 1998, Hill 1999). Glucose intolerance in adult rats exposed to maternal dexamethasone in utero has been associated with elevations in hepatic glucocorticoid receptors (GR) and glucocorticoid-sensitive enzymes involved in gluconeogenesis such as phosphoenol-pyruvate carboxykinase (PEPCK) mRNA levels (Nyirenda et al. 1998, Saegusa et al. 1999). In rats, administration of maternal carbenoxolone, an inhibitor of a placental $11 \beta$-hydroxysteroid dehydrogenase (11ßHSD) thus permitting increased passage of maternal glucocorticoids to the fetus (Whorwood et al. 1993), has been shown to reduce birth weight in a manner similar to that observed with dexamethasone treatment (Price et al. 1992, Lindsay et al. 1996, Levitt et al. 1996, Nyirenda et al. 1998). Moreover, adult male offspring demonstrated altered glucose tolerance indicated by higher fasting glucose levels and elevated glucose and insulin responses to a glucose challenge. Maternal adrenalectomy prevented this effect, supporting the role of fetal exposure to maternally derived glucocorticoids in the programming of metabolic function (Lindsay et al. 1996).

The fetal liver produces key regulators of fuel metabolism and of the developing HPA axis that are altered by glucocorticoids. The local availability of glucocorticoids is regulated, in part, by corticosteroid-binding protein (CBG), GR and by the enzyme $11 \beta \mathrm{HSD}$. CBG, cortisol's high-affinity binding protein, regulates levels of free (unbound) bioactive glucocorticoids (Ballard et al. 1982, Berdusco et al. 1993), and the 11ßHSD type 1 enzyme (11ßHSD1) (converts inactive 11-keto metabolites to bioactive glucocorticoids) (Chapman et al. 1997) regulates local tissue levels of glucocorticoids. Both CBG and $11 \beta \mathrm{HSD} 1$ are present in the fetal liver and their expression is influenced by fetal cortisol exposure in sheep (Berdusco et al. 1993, Yang et al. 1995). It is not known, however, whether repeated maternal glucocorticoid administration alters $\mathrm{CBG}$ or $11 \beta \mathrm{HSD} 1$ expression in the fetal liver. We have shown previously that repeated maternal glucocorticoid administration resulted in alterations in fetal growth and HPA function in the sheep (Sloboda et al. 2000). Repeated doses of maternal betamethasone resulted in significant reductions in fetal weight, a significant increase in cord plasma adrenocorticotrophin and a significant increase in cord plasma corticosteroid-binding capacity. We have also shown that maternal betamethasone administration resulted in significantly elevated cortisol responses to a corticotrophinreleasing hormone+vasopressin challenge in offspring at 1 year of postnatal age (Sloboda et al. 2002). These same animals exhibited significantly elevated postnatal insulin responses to a glucose load at 6 months and 1 year of age, as well as significantly higher basal glucose and glucose responses at 1 year of postnatal age (Moss et al. 2001). It is not known whether hepatic function in these offspring was altered, although it is possible that alterations in hepatic gluconeogenesis may contribute to these effects.

In order to investigate the possibility that fetal glucocorticoid exposure alters fetal hepatic glucocorticoid regulation, we set out to determine the expression levels of $11 \beta \mathrm{HSD} 1, \mathrm{CBG}$ and GR in the liver of fetal sheep at two time-points during gestation following repeated maternal betamethasone administration. Cord plasma glucose and insulin levels were also determined in order to evaluate metabolic regulation. We hypothesised that maternal betamethasone administration would result in changes in fetal regulation of intra-hepatic glucocorticoid levels that might subsequently contribute to alterations in fetal and postnatal metabolic and HPA function.

\section{Materials and Methods}

\section{Animals}

Merino ewes were mated and singleton pregnancy was confirmed using ultrasound examination at 42 days of gestation (term 150 days). Pregnant ewes were transported to a research station at 90 days of gestation and were kept in pastures, to graze in a field environment. On the evening prior to injections and later delivery, animals were brought into a nearby indoor facility.

\section{Experimental protocols}

All animals received an intramuscular injection of $150 \mathrm{mg}$ medroxyprogesterone acetate (Depo Provera; Upjohn, Rydalmere, NSW, Australia) at 98 days of gestation, as reported previously (Moss et al. 2001). This procedure has been previously shown to reduce the incidence of prenatal losses due to maternal betamethasone administration (Sloboda et al. 2000, 2002). Pregnant sheep $(n=26)$ were randomised into either control or treatment groups. Animals in the treatment group received intramuscular injections of $0.5 \mathrm{mg} / \mathrm{kg}$ maternal weight of betamethasone (Celestone Chronodose; Schering Plough, Baulkham 
Hills, NSW, Australia) at 104, 111 and 118 days of gestation. Control animals received saline injections at the same time-points. This injection protocol and dose was designed to mimic clinical administration of synthetic glucocorticoids in an obstetric environment and has been shown previously to improve lung function in fetal sheep (Ikegami et al. 1997). Ewes were sedated with maternal intramuscular ketamine $(15 \mathrm{mg} / \mathrm{kg})$ and xylazine $(0.1 \mathrm{mg} / \mathrm{kg}$ ) (Troy Laboratories, Smithfield, NSW, Australia) and spinal anaesthesia was induced by injection of 3-4 ml lidocaine (2\%). The fetus was delivered through a midline hysterotomy and arterial blood samples were collected from the umbilical cord, following which the fetus was killed by a lethal dose of pentobarbital $(30 \mathrm{mg} / \mathrm{kg}$ ). At day 125 (control $n=5$ and betamethasone $n=6$ ) and day 146 (control $n=7$ and betamethasone $n=8$ ) of gestation, fetal liver samples were collected for measurement of mRNA and protein levels. Blood samples were centrifuged at $4{ }^{\circ} \mathrm{C}$ at 10000 r.p.m. for $10 \mathrm{~min}$ and plasma was stored at $-80^{\circ} \mathrm{C}$ until later analysis. Animals were killed at these time-points in order to investigate the effects of prenatal betamethasone at a time that coincides with the maturation of the fetal HPA axis but before the onset of a significant rise in endogenous cortisol levels (125 days) and at a time when endogenous cortisol levels are at their highest (146 days or term) (Norman et al. 1985). The protocols were approved by the Institutional Ethics Committees of the Western Australian Department of Agriculture and the Animal Care Committee of the University of Toronto, according to the guidelines of the Canadian Council for Animal Care.

\section{Measurement of cord plasma glucose and insulin levels}

Cord plasma glucose levels were analysed using a glucose analyser (Beckman Glucose Analyzer 2; Beckman Instruments, Fullerton, CA, USA) via the glucose oxidase method. Cord plasma immunoreactive insulin concentrations were measured using a commercial radioimmunoassay kit (Linco Research, Inc., St Charles, MO, USA). The intra-assay coefficient of variation was $8 \%$ and the mean assay sensitivity was $0 \cdot 1 \mathrm{ng} / \mathrm{ml}$. All samples were analysed in a single assay. The insulin antibody cross-reacts $100 \%$ with rat, sheep and porcine insulin; cross-reactivity to rat C-peptide, glucagon, somatostatin, pancreatic polypeptide and insulin-like growth factor-I is undetectable (Linco).

\section{Northern blot analysis}

Northern blotting was performed as described previously (Fraser et al. 1999). Briefly, total RNA was extracted using TRIZOL reagent (Life Technologies, Inc., Rockville, MD, USA). Chloroform (Sigma Chemical Co., St Louis, MO, USA) was added to allow separation of RNA, DNA and protein. RNA was precipitated out of solution by the addition of $500 \mu \mathrm{l}$ isopropyl alcohol/1 $\mathrm{ml}$ TRIZOL, washed with $1 \mathrm{ml} \mathrm{75 \%}$ ethanol and dissolved in diethyl pyrocarbonate (DEPC)-treated water at $60{ }^{\circ} \mathrm{C}$. The purity and concentration of RNA in each sample was determined by measuring the spectrophometric absorbance (Ultrospec 2000; Pharmacia Biotech, Piscataway, NJ, USA) of isolated RNA at $260 \mathrm{~nm}$ and at $280 \mathrm{~nm}$. Ratios of the readings at 260:280 nm between 1.6 and 1.8 were considered acceptable for further analysis. The isolated RNA in each sample was assessed for integrity as follows: samples of isolated RNA $(10 \mu \mathrm{g})$ were electrophoresed on a $1 \%$ agarose formaldehyde gel, stained with ethidium bromide overnight $(0.001 \%$ (v/v) $10 \mathrm{mg} / \mathrm{ml}$ ethidium bromide, $0 \cdot 13 \%(\mathrm{v} / \mathrm{v}) 2 \beta$-mercaptoethanol), and bands visualised under UV light. Intact RNA was viewed as two distinct bands corresponding to $18 \mathrm{~S}$ and $28 \mathrm{~S}$ rRNA. Total RNA from each sample $(30 \mu \mathrm{g})$ was size-fractioned by horizontal electrophoresis (Horizon 20X25; Life Technologies, Inc.) and transferred to a nylon membrane (Zeta Probe GT Blotting membrane; Bio-Rad Laboratories, Mississauga, Ontario, Canada). The blots were prehybridised and then exposed to buffer containing ${ }^{32} \mathrm{P}$-labelled cDNA antisense probe overnight at $50{ }^{\circ} \mathrm{C}$. A labelling kit was used to label cDNA probes with $\alpha-\left[{ }^{32} \mathrm{P}\right]$ deoxy-CTP (Amersham International) using the random priming method (Ready to Go; Pharmacia-Biotech Inc., Baie d'Urfe, Quebec, Canada). The ovine full-length CBG and 11ßHSD1 cDNA sequences have been described previously (Yang et al. 1992, Berdusco et al. 1993, 1994). Each membrane was washed in $150 \mathrm{mM}$ sodium phosphate $(\mathrm{NaP}) / 0 \cdot 1 \%$ sodium dodecyl sulphate (SDS) at $55^{\circ} \mathrm{C}$ followed by washes in $30 \mathrm{mM} \mathrm{NaP} / 0 \cdot 1 \% \mathrm{SDS}$ of $15 \mathrm{~min}$ each rotating at $55^{\circ} \mathrm{C}$. Membranes were exposed to autoradiographic film (XAR-5; Eastman Kodak Co., Rochester, NY, USA) at $-80^{\circ} \mathrm{C}$, with an intensifying screen (Biomax Transcreen LE; Eastman Kodak Co.). Membranes were then stripped of the hybridised label $(0.01 \times \mathrm{SSC}, 0.5 \%$ SDS in DEPC water at $95{ }^{\circ} \mathrm{C}$ ) and reprobed with ${ }^{32} \mathrm{P}$ labelled cDNA antisense probe to mouse $18 \mathrm{~S}$ rRNA as an internal control to allow for corrections in gel loading and transfer. The signals for both the mRNA of interest and $18 \mathrm{~S}$ rRNA were analysed using an image analysis system (Imaging Research Inc., St Catharines, Ontario, Canada) within the linear range of the film and represented as relative optical densities (ROD). Results are expressed as the ratio of ROD for mRNA:18S rRNA.

\section{Western blot analysis}

Western blotting was performed as described previously (Gymorey et al. 2000). Briefly, total protein was extracted from frozen liver samples in RIPA lysis buffer $(50 \mathrm{mM}$ Tris-HCl, 1\% (v/v) Triton X-100, 0.1\% (w/v) SDS, $150 \mathrm{mM} \mathrm{NaCl}, 1 \%(\mathrm{w} / \mathrm{v})$ sodium deoxycholatic acid), with $100 \mu \mathrm{M}$ sodium orthovanadate $\left(\mathrm{Na}_{2} \mathrm{VO}_{3}\right)$ and Complete Mini EDTA-free protease inhibitors (Roche 
Table 1 Fetal glucose, insulin and I:G ratios at 125 and 146 days of gestation following either saline or maternal betamethasone administration. Values are expressed as means \pm S.E.M.

\begin{tabular}{|c|c|c|c|c|}
\hline & \multicolumn{2}{|c|}{125 days of gestation } & \multicolumn{2}{|c|}{146 days of gestation } \\
\hline & $\begin{array}{l}\text { Control } \\
(n=5)\end{array}$ & $\begin{array}{l}\text { Betamethasone } \\
(n=6)\end{array}$ & $\begin{array}{l}\text { Control } \\
(n=7)\end{array}$ & $\begin{array}{l}\text { Betamethasone } \\
(n=8)\end{array}$ \\
\hline \multicolumn{5}{|l|}{ Variables } \\
\hline Glucose (mg/dl) & $51 \cdot 7 \pm 14 \cdot 6$ & $45 \cdot 6 \pm 14 \cdot 7$ & $25 \cdot 6 \pm 2 \cdot 1$ & $41 \cdot 1 \pm 8 \cdot 1^{*}$ \\
\hline Insulin (ng/dl) & $0 \cdot 4 \pm 0 \cdot 04$ & $0 \cdot 2 \pm 0.02$ * & $0 \cdot 3 \pm 0 \cdot 03$ & $0 \cdot 3 \pm 0 \cdot 04$ \\
\hline $\mathrm{I}: \mathrm{G}$ ratio & $0.01 \pm 0.002$ & $0 \cdot 005 \pm 0.001$ & $0 \cdot 01 \pm 0.002$ & $0 \cdot 008 \pm 0 \cdot 001$ \\
\hline
\end{tabular}

${ }^{*} P<0 \cdot 05$

Diagnostics, Mannheim, Germany) and stored at $-80{ }^{\circ} \mathrm{C}$ until protein analysis. Protein concentration of each sample was determined using the Bradford assay (Bradford 1976). Proteins were separated by electrophoresis on $8 \%-12 \%$ polyacrylamide gels at $150 \mathrm{~V}$ at $4{ }^{\circ} \mathrm{C}$. Separated proteins were transferred onto nitrocellulose membranes (Bio-Rad Laboratories). The resultant blots were stained with S-Ponceau $(0 \cdot 1 \%(\mathrm{w} / \mathrm{v})$ Ponceau $\mathrm{S}$ in $5 \%$ acetic acid $(\mathrm{v} / \mathrm{v})$; Sigma Chemical Co.) to verify equal loading and transfer. The blots were washed with phosphate-buffered saline (PBS) and 0.1\% Tween-20 (Sigma Chemical Co.) and incubated overnight at $4{ }^{\circ} \mathrm{C}$ in blocking solution $(5 \%$ skim milk powder (w/v) in PBS+Tween-20) on a mechanical shaker to block non-specific binding. Blots were incubated with primary polyclonal antibodies (ovine CBG, generated in this laboratory by Berdusco et al. (1993); ovine 11ßHSD1, generated by Yang et al. (1995); and human GR, Affinity Bioreagents, Inc., Golden, CO, USA) diluted in 5\% blocking solution (5\% skim milk powder (w/v) in PBS+Tween-20) (CBG, 1:500; 11ßHSD1, 1:500; GR, $5 \mu \mathrm{g} / \mathrm{ml})$, for $1 \mathrm{~h}$. Blots were rinsed in PBS+Tween-20 for five 5-min washes. Blots were then incubated with secondary antibodies, conjugated to horseradish peroxidase (anti-rabbit Ig horseradish peroxidase; Amersham Life Sciences, Arlington Heights, IL, USA), diluted in blocking solution (CBG, 1:2000; $11 \beta$ HSD1, 1:3000; GR, 1:2000), for 1-2 h, followed by six 5-min PBS+Tween-20 washes. Detection of specific protein bands was accomplished using the electrochemiluminescence detection system (ECL; Amersham Life Sciences) and exposed to autoradiographic film (X-Omat Blue XB-1; Eastman Kodak Co.). The signals for the protein of interest were analysed using an image analysis system (Imaging Research Inc.) and represented as arbitrary optical densities (AOD).

\section{Statistical analysis}

Changes in cord plasma glucose and insulin levels, and insulin:glucose (I:G) ratios at both 125 and 146 days of gestation were analysed using an unpaired one-tailed Student's t-test. Hepatic CBG and 11ßHSD1 mRNA levels are expressed as ROD mRNA:18S rRNA ROD ratio and CBG, 11ßHSD1 and GR protein levels are expressed as AOD units and all results were analysed using an unpaired one-tailed Student's $t$-test. Statistical significance was determined as $P<0 \cdot 05$. All values are presented as means \pm S.E.M. (Sigma Stat; Jandel Scientific, Chicago, IL, USA).

\section{Results}

Effects of maternal betamethasone on cord glucose and insulin levels and $I: G$ ratios

Maternal betamethasone administration did not alter mean cord plasma glucose but significantly decreased cord plasma insulin levels (Table $1 ; P<0 \cdot 05$ ) at 125 days of gestation. The mean I:G ratio was reduced in animals treated with betamethasone but this difference did not reach significance. At 146 days of gestation, cord plasma glucose levels were significantly increased following maternal betamethasone administration (Table 1; $P<0 \cdot 05$ ), without significant alterations in plasma insulin levels. The mean I:G ratio was reduced with betamethasone treatment but this difference did not reach statistical significance.

Effects of maternal betamethasone on fetal hepatic 11ßHSD1, $C B G$ and $G R$ levels

A single transcript of $1.8 \mathrm{~kb}$ for $11 \beta \mathrm{HSD} 1$ was detected in RNA samples from fetal livers. Due to RNA degradation as shown by $18 \mathrm{~S}$ (Fig. 1), three saline-treated animals were compared with five betamethasone-treated animals. Maternal betamethasone administration significantly elevated fetal hepatic 11ßHSD1 mRNA levels at 125 days of gestation (Fig. 1; $P<0 \cdot 05$ ) and was associated with a significant increase in $11 \beta \mathrm{HSD} 1$ protein levels (Fig. 2; $P<0 \cdot 05)$. 11ßHSD1 protein levels $(34 \mathrm{kDa})$ were not different following maternal betamethasone at 146 days of gestation. In addition to the $34 \mathrm{kDa}$ band, a secondary $32 \mathrm{kDa}$ transcript was also identified in fetal liver 


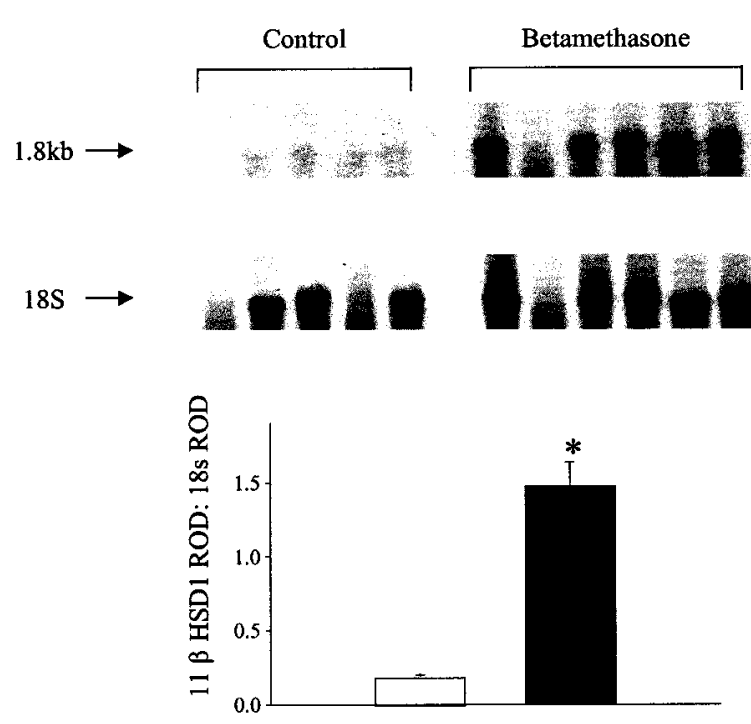

Figure 1 Fetal hepatic $11 \beta$ HSD1 mRNA levels at 125 days of gestation following either saline ( $n=3$, open bar) or maternal betamethasone administration ( $n=5$, solid bar). The autoradiograms for $11 \beta \mathrm{HSD} 1 \mathrm{mRNA}(1 \cdot 8 \mathrm{~kb})$ and control $18 \mathrm{~S}$ rRNA are shown in the upper panel. The ROD of $11 \beta \mathrm{HSD} 1$ mRNA is expressed as a ratio (11ßHSD1 ROD:18S ROD) and shown in the lower panel. Values are presented as ROD and means \pm S.E.M. Maternal betamethasone administration resulted in a significant $\left({ }^{*} P<0 \cdot 05\right)$ increase in $11 \beta$ HSD 1 mRNA levels in the fetal liver at 125 days of gestation.

homogenates at both 125 and 146 days of gestation, although to a much lesser degree. This observation is similar to previous observations in the fetal baboon placenta and liver. Pepe et al. (1999) demonstrated that the $11 \beta$ HSD1 protein size differed according to tissue type. In human and baboon syncytiotrophoblast, $11 \beta$ HSD1 was detected as a protein with an apparent molecular size of $32 \mathrm{kDa}$ while the major form in the liver appeared to be a $34 \mathrm{kDa}$ protein, with much less $32 \mathrm{kDa}$ protein levels expressed. The authors described this apparent size difference as the result of differences in the nature or number of glycosylation residues, possibly resulting from posttranslational processing. It appears that we have observed this same phenomenon in fetal sheep liver homogenates. The ratio of transcripts (32 vs $34 \mathrm{kDa}$ ) was unchanged with maternal betamethasone treatment.

A single $1.8 \mathrm{~kb}$ transcript for CBG was found in fetal hepatic RNA samples (Fig. 3). Fetal hepatic CBG mRNA levels at 125 days of gestation were significantly elevated following maternal betamethasone administration (Fig. 3; $P<0 \cdot 05$ ), and were not associated with significant alterations in CBG protein levels (57 kDa; Fig. 4). CBG protein levels in the fetal liver at 146 days of gestation were unchanged following maternal betamethasone administration (Fig. 4). Mean GR protein levels in the fetal liver were not statistically different at either 125 or 146 days of gestation after betamethasone treatment (data not shown).
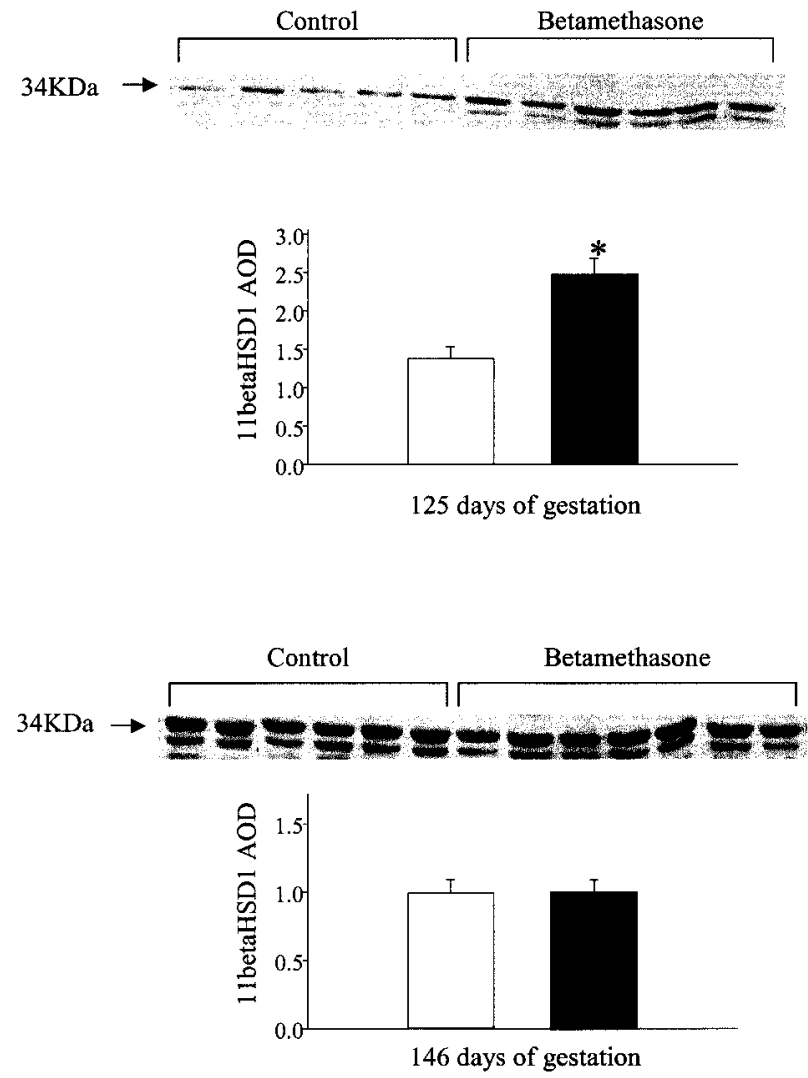

Figure 2 Fetal hepatic $11 \beta \mathrm{HSD} 1$ protein $(34 \mathrm{kDa}$ ) levels at 125 and 146 days of gestation following either saline (open bars) or maternal betamethasone administration (solid bars). Values are presented as AOD units for the $34 \mathrm{kDa}$ band and are means \pm S.E.M. Maternal betamethasone administration resulted in a significant $\left({ }^{*} P<0 \cdot 05\right)$ increase in $11 \beta \mathrm{HSD} 1(34 \mathrm{kDa})$ protein levels in the fetal liver at 125 days of gestation.

Samples were not available to analyse $11 \beta \mathrm{HSD} 1$ and CBG mRNA levels at 146 days of gestation.

\section{Discussion}

This study has demonstrated that repeated maternal administration of betamethasone in the sheep resulted in a decrease in cord plasma insulin levels at 125 days and an increase in cord plasma glucose at 146 days of gestation. Basal glucose levels at 125 days of gestation were higher and insulin levels were lower in this study than those previously reported (Houghton et al. 1989). Although this observation may suggest that these animals were stressed at the time of delivery, we have previously found that cord plasma cortisol levels in these same animals were not elevated at this time-point (Sloboda et al. 2000), therefore providing strong evidence that these sheep and this delivery model is not associated with a fetal stress response. It is possible that any discrepancy in basal glucose and 

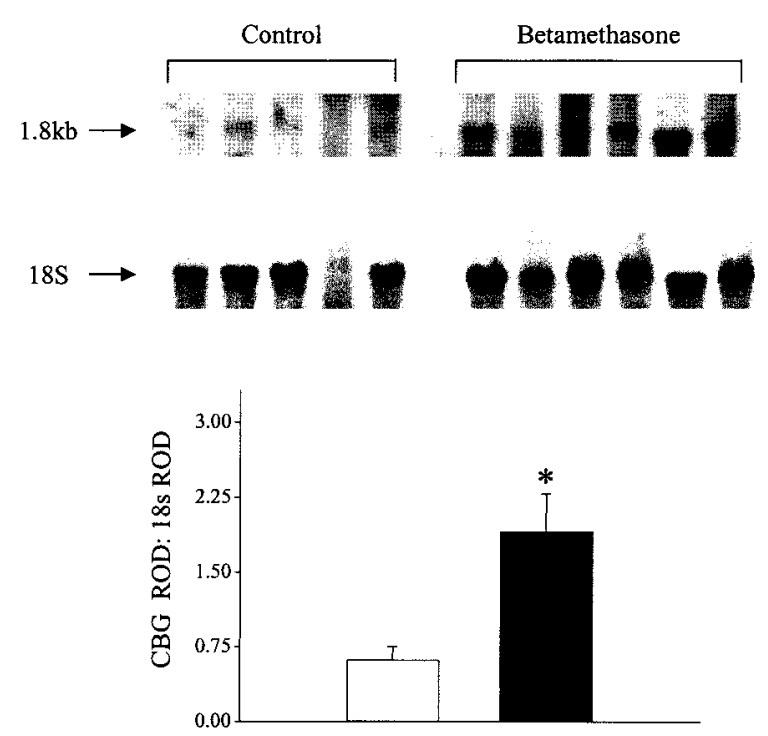

Figure 3 Fetal hepatic CBG mRNA levels at 125 days of gestation following either saline $(n=4$, open bar) or maternal betamethasone administration ( $n=6$, solid bar). The autoradiograms for CBG mRNA $(1.8 \mathrm{~kb})$ and control $18 \mathrm{~S}$ rRNA are shown in the upper panel. The ROD of CBG mRNA was expressed as a ratio CBG ROD:18S ROD and values are shown in the lower panel. Values are presented as ROD and are means \pm S.E.M. Maternal betamethasone administration resulted in a significant $\left({ }^{*} P<0.05\right)$ increase in CBG mRNA levels in the fetal liver at 125 days of gestation.

insulin values in our study and those previously published may be due to the breed of sheep or composition of their diet.

Previous studies have demonstrated that fetal glucocorticoid exposure can potentially programme pancreatic development (Phillips 1996, Seckl 1997, Hill 1999, Hill \& Duvillie 2000), although almost all evidence is derived from data collected on the rat. GR are present in the $\beta$ cells of the adult pancreas (Fischer et al. 1990) and glucocorticoids have been shown to regulate pancreatic development (Rall et al. 1977, Hill 1999). Furthermore, it has been shown previously that glucocorticoids inhibit insulin secretion from cultured adult mouse islets (Lambillote et al. 1997). It is not known whether insulin secretion was altered in the present study. It is possible that betamethasone treatment prematurely developed sympathetic suppression of insulin secretion, since previous studies have shown that glucocorticoids have a maturational effect on the sympathetic response at birth (Segar et al. 1998, 2001, 2002). We have previously shown, however, that offspring treated with prenatal glucocorticoids exhibit exaggerated insulin responses to a glucose bolus at 1 year of postnatal age, rather than inhibited insulin secretion (Moss et al. 2001). Furthermore, since cord insulin levels were not different at 146 days of gestation, any possible effect on the sympathetic regulation of insulin secretion due to betamethasone
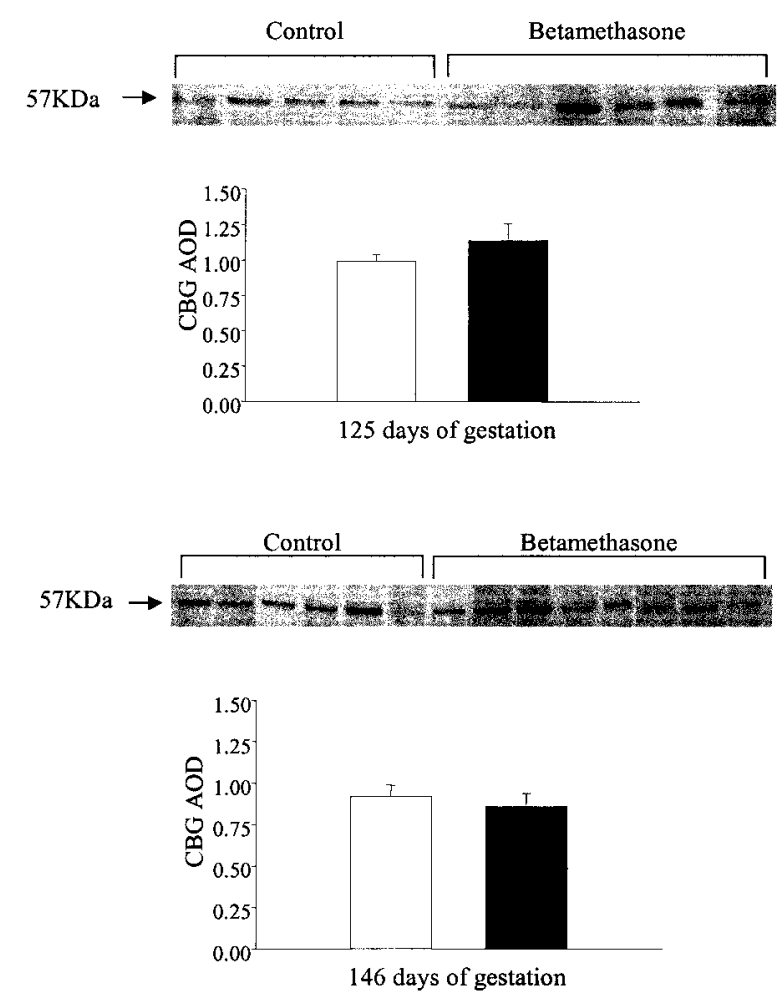

Figure 4 Fetal hepatic CBG protein $(57 \mathrm{kDa})$ levels at 125 and 146 days of gestation following either saline (open bars) or maternal betamethasone administration (solid bars). Values are presented as AOD units and are means \pm S.E.M.

treatment in this study must have been transient. Any conclusions regarding sympathetic function in these animals is not possible without further measurements of cord plasma catecholamines. Therefore, although the exact mechanisms are unknown, it appears that repeated maternal betamethasone administration of synthetic glucocorticoids in this animal model alters fetal glucose and insulin regulation.

This study has demonstrated an increase in fetal hepatic $11 \beta$ HSD 1 mRNA and protein levels as well as significant increases in CBG mRNA expression levels at 125 days of gestation following repeated maternal administration of synthetic glucocorticoids. Although it is puzzling that CBG mRNA levels were increased at 125 days of gestation without changes in protein levels, it remains possible that small changes in steady-state CBG protein levels were present but could not be detected by Western blotting, since we have demonstrated previously that repeated maternal betamethasone administration resulted in an increase in plasma corticosteroid-binding capacity at 125 days of gestation. The observations in the present study are consistent with previous studies that have reported that fetal growth restriction (McMillen et al. 2000) and fetal dexamethasone infusion significantly elevated fetal hepatic 11ßHSD1 (Yang et al. 1994) and CBG (Berdusco 
et al. 1993, Zhao et al. 1997) mRNA expression late in gestation. Furthermore, Yang et al. (1994) demonstrated that elevations in 11ßHSD1 mRNA expression levels were associated with a twofold increase in enzymatic activity, supporting the idea that glucocorticoids regulate functional activity of this enzyme. Whether the increased expression levels in this study have a functional significance is uncertain; however, given the previously established relationship between 11ßHSD1 and CBG mRNA expression and functional activity (Berdusco et al. 1994, Yang et al. 1994), it appears likely that 11ßHSD1 activity and corticosteroid binding in these animals would have increased following maternal betamethasone administration.

The role of hepatic $11 \beta$ HSD1 in facilitating an increase in local glucocorticoid concentrations in the liver has been suggested by other studies (Langlois et al. 1995, Jamieson et al. 1999, 2000). In vivo, hepatic $11 \beta \mathrm{HSD} 1$ acts primarily as a reductase enzyme, converting inactive cortisone/ deoxycorticosterone to biologically active cortisol/ corticosterone (Penning 1997, Seckl \& Chapman 2000). $11 \beta \mathrm{HSD} 1$ and GR have been co-localized in the liver of the rat (Whorwood et al. 1992) suggesting that 11ßHSD1 may regulate ligand access to GR (Whorwood et al. 1992, Jamieson et al. 2000, Seckl \& Chapman 2000). Glucocorticoids in turn regulate 11ßHSD1 expression and activity (Voice et al. 1996). CBG is primarily produced in the fetal liver (Ballard et al. 1982, Berdusco et al. 1993) and regulates local and circulating levels of cortisol, resulting in an overall decrease in bioactive glucocorticoids (Berdusco et al. 1993, Challis et al. 1995). Many studies have reported that glucocorticoids regulate both CBG expression levels and activity (Challis et al. 1985, 1995, Berdusco et al. 1993, 1994, Jeffray et al. 1995). It has been demonstrated previously that increasing levels of plasma cortisol correlate positively with the activity of key hepatic enzymes involved in gluconeogenesis, such as PEPCK and glucose6-phosphatase (Fowden et al. 1990, 1993). Moreover, in $11 \beta$ HSD1-knockout mice, gluconeogenic enzyme expression levels are reduced (Kotelevtsev et al. 1997), suggesting the importance that local tissue levels of glucocorticoids have on liver metabolic processes. Therefore, inappropriate increases in intra-hepatic levels of glucocorticoids, through a change in hepatic $11 \beta \mathrm{HSD} 1$ or CBG expression levels, could influence metabolic regulation. Previously, Nyirenda et al. (1998) have demonstrated that maternal dexamethasone administration in the rat late in gestation resulted in a decrease in birth weight, impaired glucose tolerance and a significant increase in hepatic PEPCK and GR mRNA expression in adult offspring. In the present study, fetal GR protein levels were not significantly different following maternal betamethasone. This discrepancy may be due to differences in treatment protocols. Nyirenda et al. (1998) administered dexamethasone to pregnant rats for an entire week while, in the present study, pregnant ewes were given discrete doses of betamethasone 1 week apart. It is possible that in the present study subtle changes in hepatic GR expression, as the result of betamethasone treatment, may not become evident until postnatal life. Alternatively, it may be that prenatal betamethasone administration in our sheep model results in changes in local levels of endogenous cortisol in the liver through alterations in $11 \beta \mathrm{HSD} 1$ and $\mathrm{CBG}$ expression and not alterations in GR expression.

In conclusion, the observations in this study indicate that prenatal glucocorticoid treatment results in alterations in gene expression in the fetal sheep liver and fetal glucose homeostasis. The safety and long-term implications of prenatal glucocorticoid treatment for pregnancies at risk of preterm birth in humans is currently the subject of clinical trials. The results of the present study indicate that consideration will need to be given to ongoing evaluation of individuals enrolled in these and future studies to ensure that prenatal glucocorticoid treatment is not associated with life-long compromise of metabolic function.

\section{Acknowledgements}

This work was supported by The National Health and Medical Research Council of Australia project grant number 980578, and the Women and Infants Research Foundation and the Canadian Institutes and Health Research (CIHR) Group in Fetal and Neonatal Health and Development.

\section{References}

Ballard PL, Kitterman JA, Bland RD, Clyman RI, Gluckman PD, Platzker ACF, Kaplan SL \& Grumbach MM 1982 Ontogeny and regulation of corticosteroid binding globulin capacity in plasma of fetal and newborn lambs. Endocrinology 110 359-366.

Barker DJP 1994 The fetal origins of adult disease. Fetal and Maternal Medicine Review 6 71-80.

Barker DJP 1998 In utero programming of chronic disease. Clinical Science 95 115-128.

Berdusco ETM, Hammond GL, Jacobs RA, Grolla A, Akagi K, Langlois DA \& Challis JRG 1993 Glucocorticoid induced increase in plasma corticosteroid-binding globulin levels in fetal sheep is associated with increased biosynthesis and alterations in glycosylation. Endocrinology 132 2001-2008.

Berdusco ETM, Milne WK \& Challis JRG 1994 Low-dose cortisol infusion increases plasma corticosteroid-binding globulin (CBG) and the amount of hepatic CBG mRNA in fetal sheep on day 100 of gestation. Journal of Endocrinology 140 425-430.

Bradford MM 1976 A rapid and sensitive method for the quantitation of microgram quantities of protein utilizing the principle of protein-dye binding. Analytical Biochemistry 72 248-254.

Challis JRG, Nancekieville A \& Lye SJ 1985 Possible role of cortisol in the stimulation of cortisol-binding capacity in the plasma of fetal sheep. Endocrinology 116 1139-1144

Challis JRG, Berdusco ETM, Jeffray TM, Yang K \& Hammond GL 1995 Corticosteroid-binding globulin (CBG) in fetal development. Journal of Steroid Biochemistry and Molecular Biology 53 523-527.

Chapman KE, Kotelevtsev YV, Jamieson PM, Williams LJS, Mullins JJ \& Seckl JR 1997 Tissue specific modulation of glucocorticoid 
action by the $11 \beta$ hydroxysteroid dehydrogenase. Modulators of Nuclear Receptor Function 25 583-587.

Dennison E, Fall CHD, Cooper C \& Barker DJP 1997 Prenatal factors influencing long-term outcome. Hormone Research 48 25-29.

Dodic M, Peers A, Coghlan JP \& Wintour EM 1999 Can excess glucocorticoid, in utero, predispose to cardiovascular and metabolic diseases in middle age? Trends in Endocrinology and Metabolism 10 86-91.

Fischer B, Rausch U, Wollny P, Westophal H, Seitz J \& Aumuller G 1990 Immunohistochemical localization of the glucocorticoid receptor in pancreatic $\beta$-cells of the rat. Endocrinology 126 2635-2641.

Fowden AL, Coulson RL \& Silver M 1990 Endocrine regulation of tissue glucose-6-phosphatase activity in the fetal sheep during late gestation. Endocrinology 126 2823-2830.

Fowden AL, Mijovic J \& Silver M 1993 The effects of cortisol on hepatic and renal gluconeogenic enzyme activities in the sheep fetus during late gestation. Journal of Endocrinology 137 213-222.

Fraser M, Jeffray TM \& Challis JRG 1999 Glucocorticoid effects on ovine fetal adrenal corticotrophin receptor and steroidogenic enzyme mRNA expression during late pregnancy. Journal of the Society of Gynecological Investigation 6 116A.

Gyomorey S, Gupta S, Lye SJ, Gibb W, Labrie F \& Challis JRG 2000 Temporal expression of prostaglandin $\mathrm{H}$ synthase type 2 (PGHS-2) and $\mathrm{P}_{450} 0_{\mathrm{C} 17}$ in ovine placentomes with natural onset of labour. Placenta 21 478-486.

Hales CN, Barker DJP, Clark PMS, Cox LJ, Fall CHD, Osmond C \& Winter PD 1991 Fetal and infant growth and impaired glucose tolerance at age 64. British Medical Journal 303 1019-1022.

Hill DJ 1999 Fetal programming of the pancreatic $\beta$ cells and the implications for postnatal diabetes. Seminars in Neonatology 4 99-113.

Hill DJ \& Duvillie B 2000 Pancreatic development and adult diabetes. Pediatric Research 48 269-274.

Houghton PE, McDonald TJ \& Challis JRG 1989 Ontogeny of the insulin response to glucose in fetal and adult sheep. Canadian Journal of Physiology and Pharmacology 67 1288-1293.

Ikegami M, Jobe AH, Newnham J, Polk DH, Willet KE \& Sly P 1997 Repetitive prenatal glucocorticoids improve lung function and decrease growth in preterm lambs. American Journal of Respiratory and Critical Care Medicine 156 178-184.

Jamieson PM, Chapman KE \& Seckl JR 1999 Tissue and temporal specific regulation of $11 \beta$ hydroxysteroid dehydrogenase type 1 by glucocorticoids in vivo. Journal of Steroid Biochemistry and Molecular Biology 68 245-250.

Jamieson PM, Walker BR, Chapman KE, Andrew R \& Rossiter S $200011 \beta$-Hydroxysteroid dehydrogenase type 1 is a predominant $11 \beta$-reductase in the intact perfused rat liver. Journal of Endocrinology 165 685-692.

Jeffray TM, Berdusco ETM, Wallace M, Fowden AL \& Challis JRG 1995 Effects of incremental cortisol and adrenalectomy on plasma corticosteroid binding capacity in fetal sheep. Canadian Journal of Physiology and Pharmacology 73 1568-1573.

Kotelevtsev YV, Holmes MC, Burchell A, Houston PM, Schmoll D, Jamieson PM, Best R, Brown R, Edwards CRW, Seckl JR \& Mullins JJ $199711 \beta$ Hydroxysteroid dehydrogenase type 1 knockout mice show attenuated glucocorticoid inducible responses and resist hyperglycemia on obesity or stress. PNAS 94 14924-14929.

Lambillotte C, Gilon P \& Henquin JC 1997 Direct glucocorticoid inhibition of insulin secretion. Journal of Clinical Investigation 99 414-423.

Langlois DA, Matthews SG, Yu M \& Yang K 1995 Differential expression of $11 \beta$ hydroxysteroid dehydrogenase 1 and 2 in the developing ovine fetal liver and kidney. Journal of Endocrinology 147 405-411.
Levitt NS, Lindsay RS, Holmes MC \& Seckl JR 1996

Dexamethasone in the last week of pregnancy attenuates hippocampal glucocorticoid receptor gene expression and elevates blood pressure in the adult offspring in the rat. Neuroendocrinology 64 412-419.

Levitt NS, Lambert EV, Woods D, Hales CN, Andrew R \& Seckl JR 2000 Impaired glucose tolerance and elevated blood pressure in low birth weight, non-obese, young south African adults: early programming of cortisol axis. Journal of Clinical Endocrinology and Metabolism 85 4611-4618.

Liggins GC \& Howie RN 1972 A controlled trial of antepartum glucocorticoid treatment for prevention of the respiratory distress syndrome in premature infants. Pediatrics 50 515-525.

Lindsay RS, Lindsay RM, Waddell BJ \& Seckl JR 1996 Prenatal glucocorticoid exposure leads to offspring hyperglycemia in the rat: studies with the $11 \beta$ hydroxysteroid dehydrogenase inhibitor carbenoxolone. Diabetologia 39 1299-1305.

Lithell HO, McKeigue PM, Berglund L, Mohsen R, Lithell UB \& Leon DA 1996 Relation of size at birth to non-insulin dependent diabetes and insulin concentrations in men aged 50-60 years. British Medical Journal 312 406-410.

McCance DR, Pettitt DJ, Hanson RL, Jacobsson LTH, Knowler WC \& Bennett HPJ 1994 Birth weight and non-insulin dependent diabetes: thrifty genotype, thrifty phenotype, or surviving small baby genotype. British Medical Journal 308 942-945.

McMillen IC, Warnes KE, Adams MB, Robinson JS, Owens JA \& Coulter CL 2000 Impact of restriction of placental and fetal growth on expression of $11 \beta$-hydroxysteroid dehydrogenase type 1 and type 2 messenger ribonucleic acid in the liver, kidney and adrenal of the sheep fetus. Endocrinology 141 539-543.

Moss TJ, Sloboda DM, Gurrin LC, Harding R, Challis JRG \& Newnham J 2001 Programming effects in sheep of prenatal growth restriction and glucocorticoid exposure. American Journal of Physiology 281 R960-R970.

Norman LJ, Lye SJ, Wlodek ME \& Challis JRG 1985 Changes in pituitary responses to synthetic ovine corticotrophin releasing factor in fetal sheep. Canadian Journal of Physiology and Pharmacology 63 $1398-1403$.

Nyirenda MJ, Lindsay RM, Kenyon CJ, Burchell A \& Seckl JR 1998 Glucocorticoid exposure in late gestation permanently programs rat hepatic phosphoenolpyruvate carboxykinase and glucocorticoid receptor expression and causes glucose intolerance in adult offspring. Journal of Clinical Investigation 101 2174-2181.

Osmond C, Barker DJP, Winter PD, Fall CHD \& Simmonds SJ 1993 Early growth and death from cardiovascular disease in women. British Medical Journal 307 1519-1524.

Penning TM 1997 Molecular endocrinology of hydroxysteroid dehydrogenases. Endocrine Reviews 18 281-305.

Pepe GJ, Burch MG \& Albrecht ED 1999 Expression of the 11ß-hydroxysteroid dehydrogenase types 1 and 2 proteins in human and baboon placental syncytiotrophoblast. Placenta 20 $575-582$.

Phillips DIW 1996 Insulin resistance as a programmed response to fetal undernutrition. Diabetologia 39 1119-1122.

Phillips DIW, Barker DJP, Fall CHD, Seckl JR, Whorwood CB, Wood PJ \& Walker BR 1998 Elevated plasma cortisol concentrations: a link between low birth weight and the insulin resistance syndrome. Journal of Clinical Endocrinology and Metabolism $83757-760$.

Phipps K, Barker DJP, Hales CN, Fall CHD, Osmond C \& Clark PMS 1993 Fetal growth and impaired glucose tolerance in men and women. Diabetologia 36 225-228.

Price WA, Stiles AD, Moats-Staats BM \& D’Ercole AJ 1992 Gene expression of insulin-like growth factors (IGFs), the type 1 IGF receptor, and IGF binding proteins in dexamethasone induced fetal growth retardation. Endocrinology 130 1424-1432. 
Rall L, Pictet R, Githens S \& Rutter WJ 1977 Glucocorticoids modulate the in vitro development of the embryonic rat pancreas. Journal of Cell Biology 75 398-409.

Ravelli ACJ, van der Meulen JHP, Michels RPJ, Osmond C, Barker DJP, Hales CN \& Bleker OP 1998 Glucose tolerance in adults after prenatal exposure to famine. Lancet 351 173-177.

Saegusa H, Nakagawa Y, Liu YJ \& Ohzeki T 1999 Influence of placental $11 \beta$-hydroxysteroid dehydrogenase (11 $\beta$ HSD) inhibition on glucose metabolism and $11 \beta$ HSD regulation in adult offspring of rats. Metabolism 48 1584-1588.

Seckl JR 1997 Glucocorticoids, feto-placental 11 $\beta$-hydroxysteroid dehydrogenase type 2 , and the early life origins of adult disease. Steroids 62 89-94.

Seckl JR \& Chapman KE 2000 The 11ß-hydroxysteroid dehydrogenase system, a determinant of glucocorticoid and mineralocorticoid action: medical and physiological aspects of the $11 \beta$-hydroxysteroid dehydrogenase system. European Journal of Biochemistry 249 361-364.

Segar JL, Lumbers ER, Nuyt AM, Smith OJ \& Robillard JE 1998 Effect of antenatal glucocorticoids on sympathetic nerve activity at birth in preterm sheep. American Journal of Physiology 274 R160-R167.

Segar JL, Bedell KA \& Smith OJ 2001 Glucocorticoid modulation of cardiovascular and autonomic function in preterm lambs: role of ANG II. American Journal of Physiology. Regulatory, Integrative and Comparative Physiology 280 R646-R654.

Segar JL, Van Natta T \& Smith OJ 2002 Effects of fetal ovine adrenalectomy on sympathetic and baroreflex responses at birth. American Journal of Physiology. Regulatory, Integrative and Comparative Physiology 283 R 460-R467.

Sloboda DM, Newnham J \& Challis JRG 2000 Effects of repeated maternal betamethasone administration on growth and hypothalamic-pituitary-adrenal function of the ovine fetus at term. Journal of Endocrinology 165 79-91.

Sloboda DM, Moss TJ, Gurrin LC, Newnham J \& Challis JRG 2002 The effect of prenatal betamethasone administration on postnatal ovine hypothalamic-pituitary-adrenal function. Journal of Endocrinology 172 71-81.
Uno H, Eisele S, Sakai A, Shelton S, Baker E, DeJesus O \& Holden J 1994 Neurotoxicity of glucocorticoids in the primate brain. Hormones and Behavior 28 336-348.

Voice MW, Seckl JR, Edwards CRW \& Chapman KE 1996 Hydroxysteroid dehydrogenase type 1 expression in 2S FA2A hepatoma cells is hormonally regulated: a model system for the study of hepatic glucocorticoid metabolism. Biochemical Journal 317 621-625.

Whorwood CB, Franklyn JA, Sheppard MC \& Stewart PM 1992 Tissue localisation of 11 beta-hydroxysteroid dehydrogenase and its relationship to the glucocorticoid receptor. Journal of Steroid Biochemistry and Molecular Biology 41 21-28.

Whorwood CB, Sheppard MC \& Stewart PM 1993 Licorice inhibits $11 \beta$ hydroxysteroid dehydrogenase messenger ribonucleic acid levels and potentiates glucocorticoid hormone action. Endocrinology 132 2287-2292.

Yang K, Smith CL, Dales D, Hammond GL \& Challis JRG 1992 Cloning of an ovine $11 \beta$ hydroxysteroid dehydrogenase complementary deoxyribonucleic acid: tissue and temporal distribution of its messenger ribonucleic acid during fetal and neonatal development. Endocrinology 131 2120-2126.

Yang K, Berdusco ETM \& Challis JRG 1994 Opposite effects of glucocorticoid on hepatic $11 \beta$-hydroxysteroid dehydrogenase mRNA and activity in fetal and adult sheep. Journal of Endocrinology 143 121-126.

Yang K, Matthews SG \& Challis JRG 1995 Developmental and glucocorticoid regulation of pituitary $11 \beta$-hydroxysteroid dehydrogenase 1 gene expression in the ovine fetus and lamb. Journal of Molecular Endocrinology 14 109-116.

Zhao XF, Scrocchi LA \& Hammond GL 1997 Glucocorticoids induce corticosteroid binding globulin biosynthesis by immature mouse liver and kidney. Journal of Steroid Biochemistry and Molecular Biology 60 163-169.

Received in final form 22 July 2002

Accepted 23 July 2002 